\title{
Establishing a Small Planting of Native Wildflowers from Seed 1
}

Jeffrey G. Norcini²

Interest in establishing native wildflowers has steadily increased over the past 30-40 years, and especially since the recent inception of Florida's native wildflower seed production industry.

Native flowers are more colorful than turf and attract butterflies, bees and hummingbirds. When established properly, native wildflower plantings are "low maintenance" compared to turf, but are not "no maintenance." In addition, many native wildflower species are good reseeders so don't plant wildflowers next to a turf area you want to keep weed free.

In this publication, 12 steps are described for establishing a small landscape planting of native wildflowers. Plantings can range in size from a small spot in a yard to a "mini-meadow" (Figure 1).

\section{Location, Location, Location}

Choose a site that is sunny most of the day, has well-drained soil, and is not too weedy.

\section{Determine Suitable Wildflower Species}

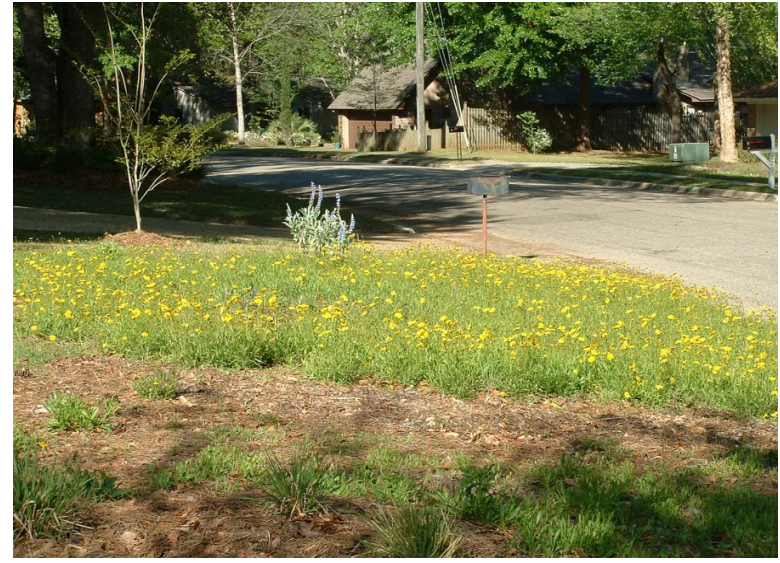

Figure 1. A "mini-meadow" of a Florida ecotype of lanceleaf tickseed (Coreopsis lanceolata) in a residential landscape. Narrow strips of turf are maintained between the planting, the road, and the neighboring property to define the planting.

Go to the Florida Native Plant Society web site (2) to find native wildflowers with the qualities (drought and salt tolerance, butterfly attraction) to fit the conditions at your site. Cross reference that with seed available from Florida's seed production co-op (3). Even if a listed species is not available, contact the

\footnotetext{
1. This document is ENH1046, one of a series of the Environmental Horticulture Department, Florida Cooperative Extension Service, Institute of Food and Agricultural Sciences, University of Florida. Original publication date December 2006. Visit the EDIS Web Site at http://edis.ifas.ufl.edu. 2. Jeffrey G. Norcini, Associate Professor, native wildflower specialist, North Florida Research \& Education Center, Quincy, FL 32351.

The use of trade names in this publication is solely for the purpose of providing specific information. UF/IFAS does not guarantee or warranty the products named, and references to them in this publication does not signify our approval to the exclusion of other products of suitable composition. All chemicals should be used in accordance with directions on the manufacturer's label. Use pesticides safely. Read and follow directions on the manufacturer's label.
}

The Institute of Food and Agricultural Sciences (IFAS) is an Equal Opportunity Institution authorized to provide research, educational information and other services only to individuals and institutions that function with non-discrimination with respect to race, creed, color, religion, age, disability, sex, sexual orientation, marital status, national origin, political opinions or affiliations. U.S. Department of Agriculture, Cooperative Extension Service, University of Florida, IFAS, Florida A. \& M. University Cooperative Extension Program, and Boards of County Commissioners Cooperating. Larry Arrington, Dean 
co-op to find out whether one of the growers has some extra seed available.

\section{Determine When to Sow Seed}

Sow seed in late August and September in north Florida and to September/October in south Florida. You might have some success by sowing seed of fall flowering species in spring.

\section{Start Preparing Site 1 Month Prior to Seeding}

One month prior to planting, spray the site with a nonselective, translocated herbicide that contains glyphosate (for example, Roundup ${ }^{\circledR}$ ) or glufosinate (for example, Finale $^{\circledR}$ ) as the main or only active ingredient. Some products might also contain diquat in addition to glyphosate or glufosinate. Do not use any product that contains any active ingredient other than these. Reapply the herbicide 2 weeks later.

\section{Mow Site 1 Day Before Seeding}

One day before sowing seed, mow the site as low as possible. Be sure that clippings are discharged away from the planting site. Rake off any remaining clippings or thatch.

\section{Scratch or Firm Up Soil}

Soil-to-seed contact is critical so 1 day before seeding, or just prior to seeding, firmer soils will have to be lightly scratched with a rake. Sandy soils might have to be made more firm by rolling to ensure that seed do not sink too deep.

\section{Sow Seed}

- Fill a large bucket about halfway with sand or vermiculite; slightly moisten the sand or vermiculite.

- Add 1/2 of the total seed and mix thoroughly.

- Starting at one end of the plot, spread the mixture evenly over the site.

- Repeat the above steps with the other $1 / 2$ of the seed but start spreading seed from the opposite end of the plot.

\section{Work Seed into Soil}

Walk over the entire site to ensure good soil-to-seed contact. Seed should be planted 1/8 inch deep to $1 / 4$ inch at most. Generally, the smaller the seed, the more shallowly it needs to be planted.

\section{Irrigate}

Irrigate the site with about $1 / 4$ to $1 / 2$ inch of water daily for about 2 to 3 weeks to speed up germination. After that, irrigate with about $1 / 2$ inch water only if the wildflowers show signs of drought stress.

\section{Keep Out the Weeds}

To minimize weed interference, mow the site as needed until the wildflower seedlings are a few inches tall. Grasses can be controlled with a "grass-only" herbicide_-available at garden centers-once the seedlings are a couple of inches tall. For details about using grass-only herbicides, see 'Weed Control' in the publication "Establishment of Native Wildflower Plantings by Seed" (1).

\section{Do Not Fertilize the First Year}

Many of Florida's native wildflower species are adapted to and perform well in soils with low fertility . Excess fertilization will promote vegetative growth over flowering, might make wildflowers more susceptible to insect and disease pests, and will promote weed growth. If you need to fertilize, wait until at least the second growing season. Use a low rate of a controlled-release fertilizer that has a low nitrogen to high potassium ratio, and that contains little to no phosphorus.

\section{Wait Until Seeds Have Matured}

Your wildflowers will reseed themselves if given the opportunity so wait until seed have matured before deadheading or mowing. For many species, seeds need 2 to 4 weeks to mature after plants bloom. Some species need longer, so check with your county extension agent or a local native plant expert.

\section{References}

1. Norcini, J.G. and J.H. Aldrich. 2004. Establishment of native wildflower plantings by seed. Fla. Coop. Ext. Serv. Publ. ENH968. http://edis.ifas.ufl.edu/ep227. 
2. Florida Native Plant Society. 2004. Natives to

plant

http://www.fnps.org/pages/plants/

landscape_plants.php.

3. Florida Wildflowers Growers Cooperative. 2006.

Seed and plants availability.

http://www.floridawildflowers.com/seed.htm. 